\title{
Investigating the interpersonal and textual meaning of Steve Jobs' Stanford speech in terms of Hyland's metadiscourse theory
}

\author{
NAN Yipei, LIU Lingling*
}

Department of English, College of Foreign Languages, China Three Gorges University, Yichang of Hubei Province, China

Email addresses:

stogether28@gmail.com (Nan. Y.), liulingling1999@hotmail.com (Liu. L.)

\section{To cite this article:}

NAN Yipei, LIU Lingling. Investigating the Interpersonal and Textual Meaning of Steve Jobs' Stanford Speech in Terms of Hyland's Metadiscourse Theory. International Journal of Language and Linguistics. Vol. 1, No. 4, 2013, pp. 90-96.

doi: $10.11648 /$ j.ij1l.20130104.12

\begin{abstract}
Despite his remarkable influence on IT industry and on our daily lives, Steve Jobs' speeches have seldom been researched. This paper sets out to explore the interpersonal and textual meaning of Jobs' famous Stanford speech in light of Hyland's theory of metadiscourse (2005). Hyland (2005) categorizes metadiscourse resources into interactional metadiscourse resources and interactive metadiscourse resources. By analyzing the interactional and interactive metadiscourse resources found in Jobs' Stanford speech, the interpersonal and textual meaning of the speech is clearly revealed. It can be concluded that by the elaborate use of various metadiscourse resources, Steve Jobs successfully projects his ideas and supports his position, and at the same time, builds a good relationship with the audience and achieve mutual communication. This article also argues that Hyland's categorization of metadiscourse, as a significant analytical framework in discourse analysis, offers a promising application in exploring interpersonal and textual meaning of language.
\end{abstract}

Keywords: Interpersonal Meaning, Textual Meaning, Interactional Metadiscourse, Interactive Metadiscourse, Metadiscourse

\section{Introduction}

It is well-known that Steve Jobs was a talented inventor and a business giant. His previous invention of commercialized personal computer pioneered technology revolution in computer industry. As the co-founder, chairman and chief executive officer of Apple Inc, Steve Jobs helped his company rocket up in performance. With the exception of his talent in science and management, what other factors contribute to his greatness and worldwide reputation? Without doubt, that is his spectacular speaking skills. No matter he gave speeches in new products promotion conferences or in schools, he could always draw audience's attention, attract their interest and receive the biggest round of applause.

This article analyzes his speech for the commencement in Stanford University in 2005. It lasts about fifteen minutes. Although this is not a long speech, it becomes one of the most influential commencement speeches of United States in recent years. In the speech, Steve Jobs talks about three stories in his life. The first story looks back his adoption, college education and finally dropping-out. He concludes that dots will somehow connect someday. The second story shows his experiences of founding Apple Company, getting fired by the company he started, and starting another company and finally returning to Apple. With these unforgotten experiences, Steve Jobs convinces students to find out what they are really fond of. The third story represents his suffering with disease. Jobs holds that one should follow his/her own heart and persist in what he/she loves. He shares his life's ups and downs, with the purpose to encourage the younger generations to be brave and positive towards life. Therefore it is not only to convey information, but also to inspire the students.

This paper sets out to explore the interpersonal and textual meaning of Jobs' Stanford speech in light of Hyland's theory of metadiscourse (2005). Hyland points out that "metadiscourse is the cover term for the self-reflective expressions used to negotiate interactional meanings in a text, assisting the writer (or speaker) to express a viewpoint and engage with readers as members of a particular community" (Hyland, 2005: 37). This definition clearly explains that a certain expression is more than giving information, but also 
contains a writer or a speaker's emotion, attitude, value and his/her aim to interact with receivers.

Hyland (2005) categorizes metadiscourse resources into interactional metadiscourse resources and interactive metadiscourse resources. By analyzing the interactional and interactive metadiscourse resources found in Jobs' Stanford speech, the interpersonal and textual meaning of the speech is clearly revealed. It can be concluded that by the elaborate use of various metadiscourse resources, Steve Jobs successfully projects his ideas and supports his position, and at the same time, builds a good relationship with the audience. This article also argues that Hyland's categorization of metadiscourse, as a significant analytical framework in discourse analysis, offers a promising application in exploring interpersonal and textual meaning of language.

\section{Theoretical Framework}

\subsection{Interpersonal Meaning and Textual Meaning of Language}

According to Halliday's Functional Grammar Theory (1994), language functions to make sense of our experience and act out our social relationships. He proposes that language has three metafunctions, namely, ideational function, interpersonal function and textual function. He suggests that interpersonal meaning of language means regarding language as an action. "When we inform or question, give an order or make an offer, and express our appraisal of and attitude towards whoever we are addressing and what we are talking about, we enact our personal and social relationships with the other people around us" (Halliday, 1994: 29). That is to say, interpersonal meaning embodies all the use of language to express one's opinion, influence one's behavior and maintain relationships with others.

Textual meaning, on the other hand, relates to construction of text. It means "being able to build up sequences of discourse, organizing the discursive flow and creating cohesion and continuity as the text moves along" (Halliday, 1994: 29). It shows the way writers organize texts and form information in texts.

\subsection{Analytical Tool: Hyland'S Theory of Metadiscourse}

\subsubsection{Definition of Metadiscourse}

Zellig Harris firstly put forward the term metadiscourse in 1959 (as cited in Hyland, 2005: 3), saying that it provides an approach to comprehending language in use, showing how a writer or a speaker guide receivers to understand the text. Williams (1981) proposes that metadiscourse can be everything but the subject matter being addressed. While, Vande Kopple raised his opinion in 1985 by stating that metadiscourse is the linguistic material that is without propositional information but that signals an author's presence. In advancing this definition forward, Crismore (1993) adds that linguistic material also intends to help the listeners or readers organize, interpret and evaluate the given information.

Except for these definitions, some other analysts define metadiscourse from different angles. Meyer (1975) puts forward a concept, signaling, which is similar to the term metadiscourse from the perspective of functional linguistics. He regards discourse as a signal which instructs semantic contents. Schifrin (1980) takes metadiscourse as meta-talk which refers to ongoing discourse, for example, "well", "I am telling you". Such words or phrases are used to organize or evaluate the ongoing discourse.

On the basis of these linguists' researches, Hyland (2005) proposes that communication is the attitudes and assumptions of those who are communicating. He presents that "metadiscourse is the cover term for the self-reflective expressions used to negotiate interactional meanings in a text, assisting the writer (or speaker) to express a viewpoint and engage with readers as members of a particular community" (Hyland, 2005:37). With the application of metadiscourse theory, our communication can be facilitated, viewpoints supported, readability improved and relationships maintained.

\subsubsection{Category of Metadiscourse}

Based on classifications given by other linguists, Hyland (2004) categorizes metadiscourse into interactive metadiscourse resources and interactional metadiscourse resources (as cited in Hyland, 2005:49). This categorization is employed here to analyze Steve Jobs' Stanford speech.

Table 1. A Model of Metadiscourse (Hyland, 2005:49)

\begin{tabular}{lll}
\hline Category & Function & Examples \\
\hline Interactive & Help to guide the reader through the text & Resources \\
Transitions & express relations between main clauses & in addition; but; thus; and \\
Frame markers & refer to discourse acts, sequences or stages & finally; to conclude; my purpose is \\
Endophoric markers & refer to information in other parts of the text & noted above; see Fig; in section 2 \\
Evidentials & refer to information from other texts & according to X; Z states \\
Code glosses & elaborate propositional meanings & namely; e.g.; such as; in other words \\
Interactional & Involve the reader in the text & Resources \\
Hedges & withhold commitment and open dialogue & might; perhaps; possible; about \\
Boosters & emphasize certainty or close dialogue & in fact; definitely; it is clear that \\
Attitude markers & express writer's attitude to proposition & unfortunately; I agree; surprisingly \\
Self mentions & explicit reference to author(s) & I; we; my; me; our \\
Engagement markers & explicitly build relationship with reader & consider; note; you can see that
\end{tabular}


This categorization reflects essential characteristics of metadiscourse. The interactive metadiscourse resources include transitions, frame markers, endophoric markers, evidentials, and code glosses. They “concern the writer's awareness of a participating audience and the ways he or she seeks to accommodate its probable knowledge, interest, rhetorical expectations and processing abilities. The writer's purpose here is to shape and constrain a text to meet the needs of particular readers, setting out arguments so that they will recover the writer's preferred interpretations and goals" (Hyland, 2005: 49). The interactional metadiscourse resources include hedges, boosters, attitude markers, self mentions and engagement markers. They "concern the ways writers conduct interaction by intruding and commenting on their message. The writer's goal here is to make his or her views explicit and to involve readers by allowing them to respond to the unfolding text" (Hyland, 2005: 49).

\section{Results}

\subsection{Interactional Metadiscourse Resources Used in the Speech}

Table 2. Interactional metadiscourse resources used in Steve Jobs'Stanford Speech

\begin{tabular}{lccc}
\hline Category & Number of terms & Percentage of total interactional metadiscourse resources & Percentage of total metadiscourse resources \\
\hline Self mentions & 148 & 63.0 & 43.0 \\
Boosters & 39 & 16.6 & 11.4 \\
Engagement markers & 22 & 9.4 & 8.0 \\
Attitude markers & 19 & 3.0 & 5.4 \\
Hedges & 7 & 100 & 68.3 \\
Total & 235 & & 6.0 \\
\hline
\end{tabular}

From this table, we can see that the total number of interactional resources is 235 , accounting for $68.3 \%$ of total metadiscourse resources used in the speech. To be more detailed, among these interactional resources, self mentions and boosters are widely used, followed by engagement markers, attitude markers as well as hedges. With the reason that speech is a very typical interpersonal activity, it is significantly important to establish a speaker identity. Therefore the wide use of self mentions makes it possible for the speaker to state his stance and perspectives more powerfully. In his speech, Steve Jobs uses 148 self mentions, accounting for closely $63 \%$ of the number of interactional resources. In addition, 39 boosters emphasize the certainty. They successfully reflect Steve Jobs' confidence in and commitment to what he is saying. These also strengthen his voice of convincing. As a result, he receives audience's comprehension and agreements. Other markers like attitude markers, engagement markers and hedges also help Steve Jobs intrude himself into the communication, facilitate the interaction, express his ideas, establish his image and bear an influence on audience.

\subsection{Interactive Metadiscourse Resources Used in the Speech}

Table 3. Interactive metadiscourse resources used in Steve Jobs 'Stanford Speech

\begin{tabular}{lccc}
\hline Category & Number of terms & Percentage of total interactive metadiscourse resources & Percentage of total metadiscourse resources \\
\hline Transitions & 85 & 78.0 & 24.7 \\
Frame markers & 20 & 18.4 & 5.8 \\
Code glosses & 2 & 1.8 & 0.6 \\
Evidentials & 2 & 1.8 & 0.6 \\
Total & 109 & 100 & 31.7 \\
\hline
\end{tabular}

From the table above, we can conclude that interactive resources have the total number of 109 , accounting for $31.7 \%$ of total metadiscourse resources found in the speech. Among these resources, transitions and frame markers rank first and second respectively, rating at the top of the interactive resources. This means that Steve Jobs is very good at organizing the text, making the text clear and coherent to audience so that it becomes easier for them to find links between arguments and to better comprehend what he conveys. Moreover, the use of code glosses and evidentials contributes to cohesion and continuity of the speech.

In conclusion, the perfect combination of interactional resources and interactive resources lead to the success of this 
speech. In the following parts, we will discuss respectively how interpersonal and textual meaning is achieved through the use of these interactional and interactive resources in this speech.

\section{Discussion}

\subsection{Interpersonal Meaning Achieved by the Use of the Interactional Metadiscourse Resources}

Delivering a speech is a typical interpersonal activity, and whether a speech succeeds or not, to a large degree, depends on the way speaker intrudes himself into the interaction. How to arouse audience interest and enthusiasm is the key point. In the speech, Steve Jobs successfully achieves interpersonal meaning by the use of the interactional metadiscourse resources.

\subsubsection{Self mentions}

Among those interactional resources, self mentions are used most. Self mentions show speaker's self-affirmation and help him improve his reliability from audience. In addition, when speaker needs to provide new information, self mentions can prove the originality of it. On the other hand, because speaker is the principal part of a speech, self mentions assist speaker to find accessible way for audience to comprehend the text. By analyzing Steve Jobs' speech, we find 148 self mentions, especially the use of first person. This makes it possible for Jobs to state his stance and perspectives and build up his speaker identity more firmly. According to Hyland (2001), self mentions have close relationship with discourse purposes:

- Self-mention is used to "address readers directly through a firm alignment with their views, pledging certainty and an interpersonal assurance of conviction" (Hyland, 2001: 221).

I'm pretty sure none of this would have happened if $I$ hadn't been fired from Apple.

This sentence shows Steve Jobs' firm conviction that being fired by Apple is not a bad thing, but provides another chance for him to realize his personal value.

I' $m$ convinced that the only thing that kept me going was that $I$ loved what $I$ did.

This sentence also reflects Steve Jobs' certainty of his own choice. To find what he loves is the only motivation for him to move forward. By stating his certainty and assurance to audience, he can easily gain audience's belief on him, create a positive image for himself, and leave a good impression on his audience.

- "One function of the first person in argument is as an exemplification device and this usage becomes not only an instrument of self-mention for the writer as scholar, but a device for inserting him as the main protagonist in illustrative examples" (Hyland, 2001: 221).

Having lived through it, $I$ can now say this to you with a bit more certainty than when death was a useful but purely intellectual concept.

When talking about death, Steve Jobs takes his own experience with disease as an example so that audience can better feel what he feels, thus making his conclusion and his speech more convincing.

- "Self- mention provides an overt structure for their discourse. It explicitly states the goal or purpose of the paper, providing an opportunity for writer to promote both themselves and their stance" (Hyland, 2001: 221).

Today $I$ want to tell you three stories from $m y$ life. That's it. No big deals. Just three stories.

From the very beginning, Steve Jobs constructs a very clear text structure for his audience, explaining the main purpose of his speech, thus making them more explicit of the text framework.

- Speakers employ first person to "summarize a viewpoint or make a knowledge claim. This use not only serves to metadiscursively guide the reader through the discussion, but once again explicitly foregrounds writer's distinctive contribution and commitment to his position" (Hyland, 2001: 222).

$I$ have always wished that for myself. And now, as you graduate to begin now, I wish that for you. Stay Hungry. Stay Foolish.

This sentence is served as a closing one, expressing Steve Jobs' best wishes for those graduates. Providing a wish, for one thing, is better to make a conclusion, for another, shortens distance with audience, and helps to gain their resonance.

\subsubsection{Boosters}

In addition, 39 boosters emphasize the certainty. They successfully reflect Steve Jobs' confidence in and commitment to what he is saying. Hyland represents "boosters suggest that the writer recognizes potentially diverse positions but has chosen to narrow this diversity rather than enlarge it, confronting alternatives with a single, confident voice" (Hyland, 2005: 52).

Again, you can't connect the dots looking forward; you can only connect them looking backwards. So you have to trust that the dots will somehow connect in your future. You have to trust in something - your gut, destiny, life, karma, whatever. Because believing in the dots will connect down the road will give you the confidence to follow your heart even when they leave you off the well-worn path. And it has made all the difference.

These inclined words and phrases can be regarded as boosters to express Steve Jobs' very positive tone of voice. People may think what they are doing now has nothing to do with what will happen to them in the future. Steve Jobs dispels this idea with his own experience. By looking back his adoption and college education and finally dropping-out, he concludes that one has to believe that dots will somehow connect someday. Things seem to be insignificant will turn out to be significant in the future. So he emphasizes the importance of having a belief. He encourages graduates to have certain faith which will make difference in their later life. Here we can conclude if one is willing to persuade others, he/she has to be very sure about his/her statements. 
Only those views which convince speaker himself/herself can talk into others.

\subsubsection{Engagement Markers}

Engagement markers focus on reader participation with two main purposes. One is to "acknowledge the need to adequately meet reader's expectations of inclusion and disciplinary solidarity, addressing them as participants in an argument", the other is to "rhetorically position the audience, pull readers into the discourse at critical points, predict possible objections and guide them to particular interpretations" (Hyland, 2005: 54).

You've got to find what you love. And that is as true for your work as it is for your lovers. Your work is going to fill a large part of your life, and the only way to be truly satisfied is to do what you believe is great work. And the only way to do great work is to love what you do. If you haven't found it yet, keep looking and don't settle.

The inclined words are listener pronouns which mark the listeners' participation. The use of second person is a face-to-face way to create friendly relations and shorten the distance between the speaker and listeners. It is easier to have a conversation with audience and express speaker's emotions so as to strengthen appeals. Here, Steve Jobs convinces students to find out what they are really fond of. Only in this way can people get over difficulties and enjoy what they engage with and experience love and passion of life. In this process, insistence is the most important factor.

I dropped out of Reed College after the first 6 months, but then stayed around as a drop-in for another 18 months or so before I really quit. So why did I drop out?

In this sentence, the question is the highlight. At the beginning of the first story, Steve Jobs uses a question to attract audience's attention and arouse their curiosity. He successfully involves audience into the discourse. As participants of the discourse, the audience will be more careful about speaker's words. Here, Steve Jobs lets audience come into his own world and has effective communication with them.

Your time is limited, so don't waste it living someone else's life. Don't be trapped by dogma - which is living with the results of other people's thinking. Don't let the noise of others' opinions drown out your own inner voice. And most importantly, have the courage to follow your heart and intuition. They somehow already know what you truly want to become. Everything else is secondary.

Here, the inclined words also can be served as engagement markers. In talking about his experience with disease, Steve Jobs holds that everyone has a limited life, so time should not be wasted in living in someone else's life. Everything is fragile in front of death, so, choose to follow one's own heart and be aware of what he/she wants to be are primary.

\subsubsection{Attitude Markers}

Attitude markers "indicate the writer's affective, rather than epistemic attitude to propositions. They convey surprise, agreement, importance, obligation, frustration and so on" (Hyland, 2005: 53).

I am honored to be with you today for your commencement from one of the finest universities in the world. Truth be told, I never graduated from college, and this is the closest I've ever gotten to a college graduation. (10)

The word honored shows that he is a modest person. No matter how famous he is, what kind of achievements he has got, he acts modestly and shows much respect for those scholars and students in Stanford University. From this word, we can see his low profile in the public. Another word finest represents his high praise to this university. This will make audience more comfortable and acceptable with the speech. This, on the other hand, reflects Steve Jobs' strategy of appealing to audience. In the next sentence, he tells a truth that he never graduated from a college. This not only indicates he is a honest man, but also makes audience think why such a famous man did not receive the high education, thus arousing their interest in listening to the speech. At the very beginning, Steve Jobs creates a very positive image of himself. Such a modest, honest and mysterious man with no doubt draws people's eyes.

And 17 years later I did go to college. But I naively chose a college that was almost as expensive as Stanford, and all of my working-class parents' savings were being spent on my college tuition.

In this sentence, the speaker uses naively to show his sense of humor and expectedly leads to laughers of all the audience. He says he chose a college as expensive as Stanford, in fact, he does not aim at the high tuition, but to break the ice and liven up the atmosphere so that he makes his speech more personal, more interesting and easier to follow.

\subsubsection{Hedges}

Hedges are not as very frequently used as other interactional resources in this speech. From our point of view, Steve Jobs' main purpose is to convince and persuade, therefore, he will not be so timid but to grasp opportunity to express his viewpoints and try to affirm his audience. He is not just a speaker, but also a businessman. If he does not represent his confidence in the public, people will of course have no confidence in him. However, boosters without hedges seem too tough, while hedges alone appear soft. So it is also essentially important to balance the use of boosters and hedges.

Reed College at that time offered perhaps the best calligraphy instruction in the country.

They somehow already know what you truly want to become.

Here, the sentence is served as an opinion rather than a fact by the usage of perhaps and somehow. This shows speaker's prudence in statement. He allows for audience's own judgment.

From the usage of interactional metadiscourse resources, we get to know how Steve Jobs bridges himself and his audience, projects his ideas and attitudes, and builds a harmonious relationship with audience. 


\subsection{Textual Meaning Achieved by the Use of the Interactive Metadiscourse Resources}

Whether a speech arouses interest or not depends highly on the construction of the text. A well-organized, smoothly-linked, flowing and fluent text with no doubt attracts attention. Steve Jobs skillfully expresses textual meaning by the use of the interactive metadiscourse resources.

\subsubsection{Transitions}

Among those interactive resources, the use of transitions ranks first. In every language, transitions play an important role in the organization of a text. Transitions work as a bridge between sentences, making them well-knitted. In Steve Jobs' speech, additions like and, transitional words such as but are highly used when talking about his different experience in his life. The high use of transitions shows the clarity and logic of sentences. On the other hand, they show the internal connections of the text, and reflect Steve Jobs' deep concerns for audience in understanding his viewpoints.

And 17 years later I did go to college.

It was pretty scary at that time, but looking back it was one of the best decisions I ever made.

From these two sentences we can see that Steve Jobs prefers to use transitions in opening and closing each section. This is good for listeners to follow his story.

\subsubsection{Frame Markers}

Frame markers can be used to "sequence parts of the text or to internally order an argument, explicitly label text stages, announce discourse goals and indicate topic shifts" (Hyland, 2005: 51).

Today I want to tell you three stories from my life.

The first story is about connecting the dots.

The second story is about love and loss.

The third story is about death.

In the beginning of the speech, Jobs clearly expresses his goal of today's speech. That is to talk about three stories. Steve Jobs is very skilled in setting the theme and hitting the major announcement of his speech. This simple but clear theme provides an easy understanding other than an ambiguous identification. Then, in the following passages, he labels stages and sequences parts of the text by providing a clear outline of the speech, and he creates a headline to set the direction for his listeners.

How can you get fired from a company you started?

Well, as Apple grew we hired someone who...

In the start of his second story, when he talks about his being fired, he questions. Then, he masterly uses a well to shift and to demonstrate his explanation. By using this kind of word, he can make the transition smoothly, thus rendering acceptable and palatable way for listeners.

\subsubsection{Evidentials}

Evidentials are things quoted from other source.

If you live each day as if it was your last, someday you'll most certainly be right.
When Steve Jobs tells his third story, he firstly represents a quote. This quote provides a necessary support for his argument on death. By quoting a motto that he loves, for one thing, shows his preference, for another, promotes the reasoning to the point. He applies this quote to illustrate that bearing death in mind will assist people to make big choice.

Stay Hungry. Stay Foolish.

This sentence is quoted from a final issue of a magazine and it has a far-reaching influence on Steve Jobs. By using this as the conclusion of his speech, he sincerely delivers his wishes for those graduates, making this speech significant and complete.

\subsubsection{Code Glosses}

Code glosses "supply additional information by rephrasing, explaining or elaborating" (Hyland, 2005: 52).

And much of what I stumbled into by following my curiosity and intuition turned out to be priceless later on.

To illustrate this view, he gives audience one example which describes how he applies what he learned in Reed College to his computer designs. From this we can see that when we are willing to interpret an argument, sometimes using an example is far more acceptable by audience, because this will not be tedious or monotonous, on the contrary, it makes the speech more interesting and sets aside a break for audience.

From the discussions above, we conclude that the wide use of interactive resources in Steve Jobs' speech leads to clarity and explicitly. The organization of the speech is accessible to the audience, so they can easily grasp the meaning it conveys. Jobs successfully guides the audience to follow his rhythm.

\section{Conclusion}

To sum up, Hyland's metadiscourse theory has so far been used to explore the interpersonal and textual meaning of Steve Jobs' Stanford speech. By discussing interactional and interactive metadiscourse resources respectively, we find out that interpersonal meaning embodies all the use of language to express one's opinion, influence one's behavior, interact with and maintain relationships with others; while textual meaning relates to construction of text, concerns with the coherence and continuity of the text. Metadiscourse Theory provides a way for mutual comprehension and involvement between the speaker and the listener. By the use of metadiscourse resources, Steve Jobs elaborately projects his ideas, supports his position, builds a good relationship with audience and facilitates mutual communication.

Since Jobs' speeches have seldom been researched by linguists so far, and Hyland's category of metadiscourse is not frequently used in discourse analysis in China, this study exhibits a certain degree of originality. The sound and updated theoretical foundation, the appropriate text sample and the logical analysis all contribute to the convincingness of this paper. We have every reason to believe that Hyland's 
theory of metadiscourse, as a significant analytical framework in discourse analysis, offers a promising application in exploring interpersonal and textual meaning of language.

\section{References}

[1] Crismore, A., et al. (1993). Metadiscourse in persuasive writing: a study of texts written by American and Finnish university students. Written Communication. 10(1), 39-71.

[2] Halliday, M.A.K. (1994). An Introduction to Functional Grammar (2nd edition). London: Edward Arnold.

[3] Hyland, K. (2001). Humble servants of the discipline? Self mention in research articles. English for Specific Purpose. 20, 207-226.

[4] Hyland, K. (2004). Genre and Second Language Writing. Ann Arbor: University of Michigan Press.
[5] Hyland, K. (2005). Metadiscourse. London \& New York: Continuum.

[6] Meyer, B. (1975). The Organization of Prose and Effect on Memory. Amsterdam: North-Holland.

[7] Schffrin, D. (1980). Metatalk: organizational and evaluative brackets in discourse. Sociological Inquiry: Language and Social Interaction. 50, 199-236.

[8] Stanford Report, (2005, June 14). "You've got to find what you love," Jobs says. Retrieved from http://news.stanford.edu/news/2005/june15/jobs-061505.ht $\mathrm{ml}$.

[9] Vande Kopple, W. J. (1985). Some exploratory discourse on metadiscourse. College Composition and Communication, $36,82-93$.

[10] Williams. R. (1981). Style: Ten Lessons in Clarity and Grace. Boston: Scott Foresman. 